\title{
ARSA wt Allele
}

National Cancer Institute

\section{Source}

National Cancer Institute. ARSA wt Allele. NCI Thesaurus. Code C103931.

Human ARSA wild-type allele is located in the vicinity of $22 q 13.33$ and is approximately 3 $\mathrm{kb}$ in length. This allele, which encodes arylsulfatase A protein, plays a role in the catabolism of cerebroside sulfate. Mutation of the gene is associated with leukodystrophy metachromatic. 